\title{
Ancient origin of Hawaiian xenoliths: fragments of mantle plume?
}

\author{
RYO FUJTAA ${ }^{1}$, AKIRA ISHIKAWA ${ }^{1}$, TETSUYA \\ YOKOYAMA $^{1}$, MICHAEL O. GARCIA ${ }^{2}$
}

${ }^{1}$ Dept. of Earth Planet. Sci., Tokyo Institute of Technology, Ookayama, Tokyo 152-8551, Japan

${ }^{2}$ Dept. ofEarth Sciences, University of Hawaii, Honolulu, HI 96822, US

Mantle xenoliths from the Salt Lake Crater (SLC), Oahu, Hawaiian Islands have been studied intensively to understand the petrography and chemistry of sub-oceanic mantle $[1,2]$. However, the origin of SLC xenoliths, which derived either from pre-existing oceanic lithosphere or accreted plume materials co-genetically related to the Hawaiian shield volcanoes, remains unclear because the SLC xenoliths are strongly metasomatized as evidenced by their identical $\mathrm{Sr}$ $\mathrm{Nd}-\mathrm{Pb}$ isotope compositions with those of the Honolulu Volcanics (HV) magma [3]. Here we investigate the abundances of highly siderophile elements (HSEs) and Re-Os isotope systematics of the peridotite xenoliths from the SLC and Kaula Island located in the southwest of Niihau. These geochemical tracers are considered to be relatively immune to secondary effects. Thus, the primary signatures of the Hawaiian mantle xenoliths can be revealed.

Whole-rock samples of the peridotite xenoliths from the SLC and Kaula Island possess similar petrological and geochemical characteristics regarding the variations in the abundances of major and trace elements as well as the HSE ratios. The variations of these parameters (e.g., $\mathrm{Ca}, \mathrm{Al}, \mathrm{Yb}, \mathrm{V}$, and $\mathrm{Pd} / \mathrm{Ir}$ ) show broad positive correlations against the wholerock ${ }^{187} \mathrm{Os} /{ }^{188} \mathrm{Os}$ ratios $(0.115-0.128)$, indicating that the peridotites are residues of variable degrees of melting. Unlike global abyssal peridotites, about $1 / 3$ the mantle xenoliths from the SLC and Kaula Island are characterized by unradiogenic ${ }^{187} \mathrm{Os} /{ }^{188} \mathrm{Os}$ ratios $(<0.120)$. Moreover, the unradiogenic samples show trends clearly resolvable from those of the global abyssal peridotites in the diagrams of $\mathrm{Ca}$, $\mathrm{Al}, \mathrm{Yb}, \mathrm{V}$, and $\mathrm{Pd} / \mathrm{Ir}$ versus ${ }^{187} \mathrm{Os} /{ }^{188} \mathrm{Os}$ ratios. Taken together, it is conceivable that the peridotite xenoliths from the SLC and Kaula Island represent ancient $(>1 \mathrm{Ga})$ depleted components in a chemically heterogeneous mantle plume as proposed by previous studies $[4,5]$.

[1] White (1966) Contr. Mineral. And Petrol. 12, 245-314. [2] Frey (1980) Am. J. Sci. 280-A, 427-449. [3] Okano \& Tatsumoto (1995) Earth Processes 135-147. [4] Bizimis et al. (2007) EPSL 257, 259-273. [5] Ishikawa et al. (2011) EPSL 301, 159-170. 